LINGUACULTURE 2, 2019

\title{
REALITY AND EVANGELISM IN THE LIFE AND WORKS OF C.S. LEWIS AND FRANCIS SCHAEFFER
}

\author{
Bruce LITTLE \\ Southeastern Theological Seminary Wake Forest, North Carolina, USA
}

\begin{abstract}
The thesis of this paper is that the shared commitment of C.S. Lewis and Francis A. Schaeffer to metaphysical realism formed the basis of their development and practice of pre-evangelism. Pre-evangelism is defined as a work to be done prior to evangelism. It appears each developed his views independent of the other suggesting it was their mutual commitment to metaphysical realism that accounts for their similar views of preevangelism. These shared ontological commitments led Lewis and Schaeffer to ask defining questions of the naturalists (Lewis) and the existentialists (Schaeffer to lead the non-believer to consider held beliefs in light of the way things are. In this way, the nonbelievers' beliefs were not first measured against Christian beliefs, but against the way creation presents itself to everybody. As Schaeffer would say, allow the non-believer to see the conclusions of his own beliefs. Put another way, Lewis would say that it was to show a person that he was wrong before showing him why he was wrong. Both believed mind independent reality as precisely the way to do this. The conclusion here is that metaphysical realism offers the same advantages for evangelism in the post Christian and atheistic atmosphere of the $21^{\text {st }}$ Century.
\end{abstract}

Keywords: C.S. Lewis, Francis A. Schaeffer, reality, pre-evangelism, metaphysical realism, anti-realism, apologetics, Bulverism, Idealism, ethics.

\section{Introduction}

C.S. Lewis and Francis A. Schaeffer are on a very short list of important Christian apologists of the twentieth century. Many consider them as important voices for Christianity in the twenty-first century especially in the area of apologetics. They had different gifts, moved in different circles but thought in similar ways. Lewis, a convert to Christianity in 1931, was an Oxford don, essayist, and author well-known for such books as Screwtape Letters and The Chronicles of Narnia. Schaeffer, an evangelical Christian thinker, missionary 
and author, spent most of his adult life in Switzerland as founder of L'Aibri. In a 1960 article in Time magazine Schaeffer was dubbed as a missionary to the European intellectuals. (“Mission to Intellectuals,” p. 63). Lewis' BBC lectures delivered during WWII were adapted and put into print under the title Mere Christianity, arguably his most popular nonfiction book. In 1965 Schaeffer delivered a series of lectures at Wheaton College titled "Speaking the Historic Christian Position into the $20^{\text {th }}$ Century", eventually edited and published as his first book, The God Who Is There, in 1968 (technically, Escape from Reason appeared first). Schaeffer is also well known for his popular book and film series, both under the title: How Should We Then Live: The Rise and Decline of Western Thought and Culture.

As shall be argued, one idea they shared in common as Christian apologists was what Schaeffer referred to as pre-evangelism and Lewis referred to it as praeparatio evangelica (preparation for the gospel as in Eusebius' Praeparatio Evangelica). What is interesting is they apparently developed this approach in evangelism quite independent of the other. To the best of my knowledge, there was never any correspondence between them nor is there any evidence they ever met. ${ }^{1}$ What is known is that Schaeffer had read some of Lewis. In Schaeffer's book Back to Freedom and Dignity, when discussing the disturbing direction of science in the $20^{\text {th }}$ century, Schaeffer wrote: "Here is C.S. Lewis's That Hideous Strength with a vengeance. I strongly urge Christians to read carefully this prophetic piece of science fiction. What Lewis casts as a warning in the form of fantasy and science fiction is much closer today" (Back to Freedom 1:371). So on what grounds did they both develop the apologetic approach to evangelism known as pre-evangelism? It is the thesis of this paper that it was their mutual commitment to metaphysical realism that accounts for their shared views of pre-evangelism.

Metaphysical realism affirms that reality is mind independent and objects that populate creation have natures (essences) that determine their ontological status-what they are. This view is often referred to as essentialism or Platonism which affirms the existence of abstract objects including essences. Plato referred to them as Forms. Under this view, the ontological status of objects in this world is determined by their nature independent of what we think of them. As Paul Tyson writes: "To Plato intelligible essence is a deep feature of

\footnotetext{
${ }^{1}$ I have researched the Francis Schaeffer Collection at the library of Southeastern Baptist Theological Seminary, Wake Forest, North Carolina and can find no correspondence between the two although there is some evidence that Schaeffer was familiar with at least some of Lewis' writings. Of course, Lewis and Schaeffer traveled in different circles. One lived in England and the other in Switzerland. It is possible Lewis may have been aware of Schaeffer through the article on Schaeffer that appeared in the 1960 Time article. I have also read the last two volumes of The Collected Letters of C.S. Lewis and found no mention of Schaeffer there.
} 
reality, it is not something subjectively generated within our consciousness and then projected onto a meaningless objective cosmos” (p.71). This means that reports about this world can be objectively true or false; right or wrong. Metaphysical realism sustains and orders our material reality giving it meaning and telos.

Lewis and Schaeffer believed all reality was grounded in God the Creator and that man was made in the image of God. The intellectual climate in the West in the $20^{\text {th }}$ Century, however, was reflecting an ever-increasing denial of anything transcendent in any objective sense. In turn, this change in the vision of reality gave birth to new and different ways to define life, man, hope, values, and moral traditions, the very things on which the cultural heritage of the West had been built. Schaeffer, in his books Escape from Reason and How Should We Then Live? explained the consequences of this ontological shift in the West from theism to naturalism. Logically, the naturalistic vision of reality led to relativism, relativism at every cultural level as pointed out by Richard Weaver in $1947 .^{2}$ In the midst of this relativism, Lewis argued for the idea of right and wrong on the basis of natural law which he said was in the "class of mathematics" (Mere Christianity, p. 10). He referred to this as the Tao by which he meant the doctrine "of objective value, the belief that certain attitudes are really true, and others really false, to the kind of thing the universe is and the kind of things we are" (The Abolition, p. 29). For Lewis (Schaeffer and Weaver), moral/ethical relativism resulted from the rejection of metaphysical realism and yet, it was precisely in the midst of this relativistic intellectual climate that Lewis and Schaeffer appealed to objective reality to begin conversation that would lead to the God who is there.

In sum, the denial of anything above experience took the form of atheism in the UK, and on the Continent where Schaeffer ministered, the alternative was secular existentialism. Atheism led to the notion man lives in a mechanistic world where everything is simply a matter of biochemical cause and effect. On this view, meaning rested on function, not on universal law, hence relativism. Secular existentialism, on the other hand, left man without meaning at all. Meaning, at best, might be achieved by the will to power as seen in Fredrick Nietzsche which was always short lived. Secular existentialism affirmed that man was what he did-existence precedes essence. In sum, both views ultimately left man without anything to claim objectively as right or

\footnotetext{
${ }^{2}$ Richard Weaver in 1947 wrote: "The issue ultimately involved is whether there is a source of truth higher than, and independent of, man; and the answer to the question is decisive for one's view of nature and destiny of humankind.” The denial of universals carries with it the denial of everything transcending experience. The denial of everything transcending experience means inevitably-though ways are found to hedge on this - the denial of truth. With the denial of objective truth there is no escape from the relativism of 'man the measure of all things'.” (Ideas Have Consequences , pp. 3-4).
} 
wrong. Lewis and Schaeffer engaged in pre-evangelism as a way to call man back to view seriously his beliefs in light of the world around him —a reality that was objective as attested to by everyday common experience where objective right and wrong still held a place. Both maintained this was necessary before any meaningful conversation about God could be had.

\section{Pre-Evangelism}

The apologetic value of metaphysical realism turns on the fact that the reality in which all live is not created by human minds, that is to say, it is mind independent. This is the way we must live, that is, we do not bend reality to fit our minds, our minds must conform to reality as it is. This means, in general, any belief about the world can be measured for truth value by submitting it to external reality. As Paul Tyson noted, "No operational understanding of reality is simply pragmatic; every time we plan or perform any activity in what we take to be a realistic manner, we do so by putting our confidence in a set of deeply held beliefs about the nature of reality itself (p.1). Like Tyson, both Lewis and Schaeffer realized that one's vision of reality informed his beliefs about the world and man.

Working from the position of metaphysical realism, Lewis and Schaeffer first engaged a person by asking questions to reveal the state of consistency between one's beliefs and the world in which one lived. The idea was to bring the non-believer to a point of realization there was something amiss in his beliefs when measured against reality if serious contradiction arose. It was showing that a person is wrong, before showing why she was wrong. This is not to imply that either was suggesting that pre-evangelism was needed in every witnessing encounter nor did it imply they doubted the power of the Gospel. Rather, it was pointed at the general intellectual atmosphere of their respective ministry environments.

Schaeffer called this "pre-evangelism" which he said was "no soft option" (Is There 1:149). Lewis referred to his approach as "praeparatio evangelica" (preparation for the gospel). In a letter to Sister Penelope, CSMV, speaking of his radio talks to the R.A.F, Lewis explains: "mine are praeparatio evangelica rather than evangelium, an attempt to convince people that there is a moral law, that we disobey it, and that the existence of a Lawgiver is at least very probable and also (unless you add the Christian doctrine of the Atonement) imparts despair rather than comfort" (The Collected Letters of C.S. Lewis, pp. 484-5). Lewis writes in a letter to Giovanni Calabria: "For my part I believe we ought to work not only at spreading the Gospel (that certainly) but also at a certain preparation for the Gospel. It is necessary to recall many to the law of nature before we talk about God. For Christ promises forgiveness of sin; but 
what is that to those who, since they do not know the law of nature, do not know they have sinned" (Collected Letters, p. 365). Grounded in metaphysical realism, pre-evangelism moves from ontology to epistemology. Pre-evangelism answered what Jacques Ellul had in mind when he spoke of finding a door to present the Gospel. He wrote:

The gospel no longer penetrates. We seem to be confronted by a blank wall. Now if we want to go further, either we must find a door, or we must break down the wall. But first we must investigate this wall, in order to find out whether there is a door: thus, we need to explore this world in which we are living. If there is not a door (as seems to me to be the case) then we must find (or create) the instruments we need in order to make a breach in it

(The Presence of the Kingdom, p. 115).

Lewis and Schaeffer found such a door based on their vision of reality-preevangelism.

Pre-evangelism did not begin by arguing with the non-Christian about her view of truth. Instead, beginning with her view of reality and hence her beliefs, pre-evangelism helped place her beliefs against reality itself to see if they rang true to what is. This was not just the reality of the physical world, but also the moral structure of man's mind. Schaeffer noted: "The truth that we let in first is not a dogmatic statement of the truth of the Scriptures, but the truth of the external world and the truth of what man himself is (Schaeffer The God, 1:138). According to Schaeffer, the Christian should then lovingly push the nonChristian until she could see that her beliefs did not fit with herself or her world. One could begin with reality and move to the truth of Christianity. As Schaeffer pointed out: "The truth of Christianity is that it is true to what is there (Schaeffer The God 1:290). Lewis noted that "the universe rings true wherever you fairly test it (Surprise by Joy, p. 177). For Lewis and Schaeffer reality provided testing ground for one's beliefs. They believed this prior work was often necessary for eventual conversation for the truth of the Gospel where atheism and existentialism prevailed.

\section{Realism not Rationalism}

Lewis and Schaeffer understood that each vision of reality, when practiced consistently, determines what one makes of his world and how one thinks about truth. Naturalistic realism (or scientism) admits only empirical evidence approved by science as material for truth. This vision puts the discussion of God and things of the transcendent realm off limits. In such an intellectual environment, thoughts of God by anyone makes him guilty of 'wishful thinking' . Lewis made this point as well in The Pilgrim's Regress (pp. 52-4). 
Another vision of reality that had gained currency in the $20^{\text {th }}$ century was that of anti-realism (philosophically known as Idealism and eventually post modernism). This view was popular on the Continent in Schaeffer's day in the form of secular existentialism. When speaking to one holding such a view, logical arguments for truth would be meaningless.

In such intellectual environments, still Lewis and Schaeffer believed that Christianity could be presented and defended on rational grounds, not to be confused with rationalism. Getting to that point, however, would require some pre-evangelism-preparing the mind for evangelism. Their commitment to rational presentation did not necessarily mean formal arguments such as theistic arguments for God's existence although these might in some way be useful at certain points. What was meant by the notion of rational was that there "are good and sufficient reasons to know that Christianity is true" (Schaeffer, The God 1:182). Rational discourse meant that the Christian message made sense in the face of what is. That is, it fits with the moral and rational structure of the universe and is consistent with how man actually lived. As Schaeffer pointed out: "Rational means that the things which are about us are not contrary to reason; or, to put it another way, man's aspiration of reason is valid, and so, the Judeo-Christian position is rational, but it is the very antithesis of rationalism (Schaeffer, The God 1:189). The world in which man lived as well as man himself was the creative work of a rational being, God. All creation was the outworking of God's thoughts (not in any Hegelian sense) materialized by the power of his word (Heb 1:1-4). Although Lewis and Schaeffer believed in rational discourse, they warned against making the defense of the Christian Faith rationalistic where reason alone would be left to do the work of evangelism. Both recognized the role of the Holy Spirit in all apologetic endeavors. As Schaeffer wrote, "Giving the answers does not stand in a dichotomy with our being careful not to minimize the work of the Holy Spirit (Schaeffer, The God 1:185). This was not merely an intellectual game as Lewis wrote: "But I have been present when an appeal of a much more emotional and also more 'pneumatic', kind has worked wonders on a modern audience. Where God gives the gift, the 'foolishness of preaching' is still mighty" (Present Concerns, p. 66).

\section{Personal Narratives}

It is interesting that metaphysical realism played a part with both Lewis and Schaeffer with respect to their personal struggle with the question of truth. Lewis documented his early intellectual struggle both in The Pilgrim's Regress and Surprised by Joy, a struggle that eventually led him to embrace Christianity. In reflection of his own journey he wrote: "On the intellectual side of my own progress had been from 'popular realism to Philosophical Idealism; from Idealism to Pantheism; from Pantheism to Theism; and from Theism to 
Christianity. I still think this is a very natural road, but I now know that it is a road very rarely trodden (The Pilgrim's, p. 231). As Lewis worked through the different views of reality early in his life, he followed them to their conclusion to see if, in fact, they could account for what was known about the world in which he found himself.

Schaeffer, working through the issue of the truth of things, did so beginning with Greek philosophy as documented by biographer Colin Duriez (Francis Schaeffer, pp. 20-21). Schaeffer considered how each philosophy answered the big questions of life to determine the truth of the claims of each. In a later crisis of faith Schaeffer once again worked through his beliefs in light of the external reality of this world. This is documented in his book True Spirituality (3:196).

I think it is not a stretch to say that the personal struggles of both Lewis and Schaeffer helped them in dealing with others who were not yet Christians. On the one hand, they had put their beliefs up against the reality in which they lived to determine the truth of things. This included their religious beliefs as well as beliefs about the world. Christianity could not escape the test of reality any more than other belief systems. Through this process not only did other belief systems fail, but Christianity explained in a consistent fashion the truth of things. Christian truth is true to what is. Therefore, when speaking with a non-Christian, their pre-evangelism moved the non-Christian to do the same thing with his beliefs as a way of testing them for truth value. Furthermore, they did not engage the non-Christian in some intellectually indifferent fashion. Rather, they were moved with compassion when dealing with the non-Christian who had honest questions. Schaeffer wrote, speaking of pre-evangelism, "As I push the man off his false balance, he must be able to feel that I care for him" (The God 1:138). Both Lewis and Schaeffer knew the importance and the anguish of struggling with the big questions of life. When dealing with others who were in the state they themselves had been, they took seriously the weight of the struggle.

\section{Realism in Apologetics}

As noted, Lewis' and Schaeffer's metaphysical realism informed their apologetic approach. As understood by both, pre-evangelism works because there is a reality independent of the mind including the transcendent realmsomething that stands above all else, by which all else can be measured. Reality being independent of the mind allows for a common rubric by which each person's beliefs can be judged for truth value. This is true of the moral side of things as well. It was the objective universal moral law that the moral ordering judged alike, king and servant.

As pointed out earlier, metaphysical realism, often associated with Plato, was observed to resonate with Christianity as seen in early church history. Tyson 
reminds us that "In sum, early Christians thinkers often found deep grounds of commonality between aspects of Greek philosophy and what they recognized as truth from within their Christian understanding of reality" (Returning, pp. 11454). While Lewis and Schaeffer, along with early Christian thinkers, agreed for the most part with the Platonic vision of reality, they realized that at points Plato was lacking understanding or even in error as he did not have the benefit of special revelation, or so it seems.

Schaeffer explained: "Plato understood that you have to have absolutes, or nothing has meaning. But the difficulty facing Plato was that his gods were not big enough to meet the need. So, although Plato knew the need, the need fell to the ground because his gods were not big enough to be the point of reference or place of residence for his absolutes, for his ideals (He Is There and He Is Not Silent 1:287).

Likewise, Lewis presented a Platonic vision of reality in the Chronicles of Narnia. In The Last Battle Lord Digory explained why the new Narnia looked something like the old Narnia, only brighter, richer, and more wonderous. He exclaimed: "“All the old Narnia that mattered, all the dear creatures, have been drawn into the real Narnia through the Door. And of course, it is different; as a real thing is from a shadow or as waking life is from a dream." After "he added under his breath, 'It's all in Plato, all in Plato: bless me, what do they teach them at these schools!”” (Lewis, The Last Battle, p. 212).

However, in a letter to Dom Bede Griffiths, OSB, Lewis separated from Plato on the view of matter. He wrote: "But I fear Plato thought the concrete flesh and grass bad and have no doubt he was wrong (Lewis, The Collected 2:326). In The Pilgrim's Regress, Lewis made the point that the material good is good. He did this through a conversation between Vertue and the Guide. ${ }^{3}$ Vertue asked, "Is it wholly wrong to be ashamed of being in this body?" The Guide responded, "The Landlord's Son was not. You know the verses- 'When thou tookest upon thee to deliver man'” (Lewis, The Pilgrim's, p. 189). According to Lewis, Plato had the right idea, but apparently lacked knowledge of the true and living God to give his view a completeness, a position shared by Schaeffer and, it should be added, by early Christian thinkers.

\section{Christian Realism and Pre-Evangelism}

As part of their vision of reality, both believed in the historic fall as taught in Genesis three. Christianity presents a vision of reality different than other religions. For Christianity creation started out as something good, in fact, very good and then something happened. Of course, that something was the sin of

\footnotetext{
${ }^{3}$ For those not familiar with The Pilgrim's Regress, the Landlord is God the creator and His Son is Christ.
} 
Adam. In The Pilgrim's Regress Lewis gave a wonderful picture of this. John (the pilgrim) and his current traveling companion (Vertue) encounter Mother

"Do you not think this Landlord of yours is a very strange one?” he asked. "How so?” said she.

"Why does he make a road like this running up to the very edge of a Precipice-unless it is to encourage travelers to break their necks in the dark?"

"Oh bless you, he never left it like that," said the old woman. "It was a good road all round the world when it was new, and all of this gorge is far later than the road."

"You mean," said Vertue, "that there has been some sort of catastrophe.

(The Pilgrim's Regress, pp. 79-80).

In the next section Lewis tells the story in allegorical form about the fall of man and subsequent consequences for all creation.

Likewise, Schaeffer's vision of reality included a time-space fall of historic Adam. Christian truth could explain the human dilemma of how man could do both good things and great evil. He wrote: "By the action of one man in a historic, space-time situation, sin entered into the world of men. But this is not just a theoretical statement that gives us a reasonable and sufficient answer to man's present dilemma, explaining how the world can be so evil and God still be good. It is that in reality, from this time on, man was and is a sinner (Genesis In Time 2:61). On the other hand, Schaeffer argued that although man was finite and cruel, he was a noble creature. He wrote:

Perhaps you do not like the word nobility, but whatever word you choose, there is something great about man. I want to add here that evangelicals have often made a serious mistake by equating the fact that man is lost and under God's judgment with the idea that man is nothing-zero. This is not what the Bible says. There is something great about man, and we have lost perhaps our greatest opportunity of evangelism in our generation by not insisting that it is the Bible that explains why man is great (He Is There 1:278).

This view of man made it possible for Schaeffer to talk with the non-Christian meaningfully as he respected the humanness or what he called the mannishness of man.

Based upon this vision of reality, both practiced pre-evangelism with great seriousness. It was a vision that fit the truth of things that provided the grounds whereby human activity could be characterized, some as blameworthy and some as praiseworthy. Of course, with naturalism there was no ground for such language and Lewis was moved to show modern man that his naturalism left him without answers on this account of things. He thought it important to show man that he was wrong, and he used reality to do this. Of course, in doing 
this, he knew that it would lead one to despair if there was no God. In a Christmas sermon (1940's), Lewis explains what he meant by the notion of "despair not comfort" which revealed his thinking about pre-evangelism. Stephanie R. Derrick wrote concerning C.S. Lewis’ Christmas sermon,

Real Pagans differ from post-Christians, Lewis continued, firstly in that they were actually religious: "To [the Pagan] the earth was holy, the woods and waters were alive." Secondly, they "believed in what we now call an 'Objective' Right or Wrong," that is, that "the distinction between pious and impious acts was something which existed independently of human opinions." Finally, Pagans, unlike "post-Christian man," had "deep sadness" because of their knowledge that they did not obey the moral code perfectly. To compensate for this shortcoming, the Pagan developed a wealth of ceremonies to "take away guilt (“Christmas and Cricket” np).

Lewis' point being that in a world of anti-metaphysical realism (post-Christian) there was no sense of personally offending a higher power because none existed. The post-Christian man must first learn of the bad news, namely that he is a sinner which explains his ugly propensities before hearing the Good News. As a post-Christian naturalist, the bad news left man without a remedy because there was no God to forgive. According to Lewis, until the post-Christian man's vision of reality is corrected, the Gospel message is meaningless. In this case, when dealing with the post-Christian the diagnosis is part of pre-evangelism. For Lewis it involved bringing the person to the point of despair before giving the message of comfort-the Good News.

Schaeffer spoke of this in terms of 'taking off the roof', to show man the bad news, namely that his vision of reality failed him on several levels. He explained how pre-evangelism works by using the analogy of removing a roof from a structure. He wrote: "It is like the great shelters built upon some mountain passes to protect vehicles from the avalanches of rock and stone which periodically tumble down the mountain." He went on to say: "The Christian, lovingly, must remove the shelter and allow the truth of the external world and of what man is, to beat upon him. When the roof is off, each man must stand naked and wounded before the truth of what is." A little later he explained: "The Scriptures then show him the real nature of his lostness and the answer to it" (The God 1:140-1). Both Lewis and Schaeffer explicitly used reality itself in this work of pre-evangelism, but both were quick to say that then we must compassionately then give the Gospel. 


\section{Testing Claims of Reality}

Lewis and Schaeffer realized that the ontological and epistemological commitments of the first 1700 years of western history were being abandoned. In this intellectual context, Lewis highlighted the concept of Bulverism, which is the idea that you "assume that your opponent is wrong and then explain his error, and the world will be at your feet." On the other hand, if you "attempt to prove that he is wrong or (still worse) try to find out whether he is wrong or right, and the national dynamism of our age will thrust you to the wall" (Lewis, "Bulverism", p. 19). Lewis explained: "In other words, you must show that a man is wrong before you start explaining why he is wrong" ("Bulverism”, p. 19). This could be done by having the post-Christian see how her beliefs about the world in general and truth in particular do not fit with the way the world is. For Lewis reality was a great teacher, he wrote:

What I like about experience is that it is such an honest thing. You may take any number of wrong turnings; but keep your eyes open and you will not be allowed to go very far before the warning signs appear. You may have deceived yourself, but experience is not trying to deceive you. The universe rings true wherever you fairly test it.

(Surprised by Joy, p. 177)

One sees this clearly in book four of The Pilgrim's Regress.

Likewise, Schaeffer believed that reality is a great teacher. Schaeffer reminded us: "This means that we do not try first to move a man away from the logical conclusion of his position but towards it. We should try to move him in the natural direction his presuppositions take him" (The God 1:138. Schaeffer was certain that any non-Christian vision of reality would fail at the end when carried out to its logical conclusion. Man, Schaeffer said will intuitively build a shelter, so to speak, to protect him from the inconsistencies. But the Christian gently removes the shelter and allows Reality to judge the truthfulness of one's beliefs as everybody lives in the same reality-an objective reality. This reality, according to Schaeffer, falls into two parts: "the fact that the universe truly exists and it has a form, and then what I would call the 'manishness' of manwhich is my own term for meaning that man is unique. People have certain qualities that must be explained" (The God 1:138). Once one's beliefs have collided with reality, now the Gospel, the Good News, comes to offer man a true place of safety.

\section{Ethics, Reality and Pre-Evangelism}

Both Lewis and Schaeffer believed one place where reality would judge modern man was in the area of morals. Given their vision of reality, categories of right 
and wrong were inescapable in humanity as the law of God was written on the heart as part of God's image in them. This internal law was a mirror of God's universal moral law whereby human acts and thoughts could be judged. Lewis appealed to the universal which he called the real Right. He wrote:

The moment you say that one set of moral ideas can be better than another, you are, in fact, measuring them both by a standard, saying that one of them conforms to that standard more nearly than the other. But the standard that measures two things is something different from either. You are, in fact, comparing them both with some Real Morality, admitting that there is such a thing as a real Right, independent of what people think, and that some people's idea gets nearer to the real Right than others (Mere Christianity, p. 11).

Likewise, Schaeffer spoke about all men having a sense of "moral motions.” He said, "you may ask why I use the term 'moral motions.' I choose the term simply because I am not talking about specific norms. I am talking about the fact that men have always felt that there is a difference between right and wrong. All men have this sense of moral motions" (Schaeffer, He Is There and He Is Not Silent 1:295). Schaeffer noted: "It is not surprising that if a reasonable God created the universe and put me in it, he should also correlate the categories of my mind to fit that universe, simply because I have to live in it" (Schaeffer, He Is There 1:195). Even atheist Marc Hauser agrees there are moral universals (Hauser), but would deny they come from God.

In sum, Schaeffer underscores the importance of metaphysical realism when he writes: "The Christian has a certainty right from the start that there is an external world that is there, created by God as an objective reality. He is not like the man who has nowhere to begin, who is not sure that there is anything there" (He Is There 1:134-55). As Schaeffer pointed out: "The loss of the certainty of objectivity is a serious thing to the scientist, just as it is for the drug addict" (He is There 1:334-5). This means, generally speaking, the evangelist's first work is to prepare the unbeliever for the Gospel by looking at the truth of things to help him see where his beliefs may run contrary to reality or as Lewis would say 'the real Right'. On this view of evangelism, one should listen carefully to honest questions and give honest answers-answers that fit the way the universe including man is. This is precisely how both Lewis and Schaeffer engaged the post-Christian using pre-evangelism based upon their metaphysical realism. Of course, if a person is ready to listen to the Gospel carefully then there would be no need for pre-evangelism.

\section{Conclusion}

Pre-evangelism as understood by Lewis and Schaeffer rested on their metaphysical vision of reality which is absolutely core to understanding their 
pre-evangelism. Metaphysical realism is not a conclusion of pre-evangelism; it rather is the philosophical prerequisite for pre-evangelism. Pre-evangelism itself does not necessarily require a commitment to natural theology as might be tis generally considered, only that reality is mind independent, making reality a means by which one's beliefs about man and his world can be assayed for truth value. When one's beliefs run contrary to what is, that person must either disregard the conflict or work to re-calibrate her beliefs to correspond to the truth of things. Pre-evangelism allows the debate about beliefs to begin with the post-Christian's beliefs as measured by the truth of things (reality); not the postChristian's beliefs against the Christian's beliefs. This seems to me a most valuable evangelistic paradigm as it begins with pre-evangelism. It removes, from the start, this unprofitable debate that puts my beliefs against your beliefs. It is about using reality showing that a person is wrong before showing him why he is wrong. In this, despair, or crisis to use Schaeffer's term, often must come first, only to be closely followed by the Good News that is found in the Christian scriptures.

\section{Works Cited}

Derrick, Stephanie L. “Christmas and Cricket: Finding Two Lost C.S. Lewis Articles. "Christianity Today, December 18, 2017. https://www.christianitytoday.com/ct/2017/december-web-only/christmascricket-lost-c-s-lewis-articles.html Web 3 September 2018.

Duriez, Colin. Francis Schaeffer: An Authentic Life. Wheaton: Crossway, 2008. Print.

Ellul, Jacques. The Presence of the Kingdom, $2^{\text {nd }}$ Edition. Colorado Springs: Helmers \& Howard, 1989. Print.

Hauser, Marc. Moral Minds: How Nature Designed Our Sense of Right and Wrong New York: HarperCollins, 2006.

Lewis, Clive Staples. The Abolition of Man. New York: The Macmillan Publishing Company, 1965. Print.

---. "Bulverism". Compelling Reason: Essays on Ethics and Theology, Ed. Walter Hooper. London: William Collins, 2017. Print.

---. The Collected Letters of C.S. Lewis, Ed. Walter Hooper, vol 2. New York: HarperCollins Publishers, 2004a. Print.

---. The Collected Letters of C.S. Lewis, Ed. Walter Hooper, vol 3. New York: HarperCollins Publishers, 2004b. Print.

---. The Last Battle. New York: HarperCollins Publishers, 1994. Print.

---. Mere Christianity. New York: Macmillan Publishing Company, 1960. Print.

---. The Pilgrim's Regress: Wade Annotated Edition. Edited and introduced by David Downing. Illustrated by Michael Hague. Michigan: William B. Eerdmans Publishing Company, 2014. Print.

---. Present Concerns: A Compelling Collection of Timely, Journalistic Essays. Ed. Walter Hooper. San Diego: A Harvest Book, 1986. Print. 
---. Surprised By Joy. San Diego: Harcourt Brace, 1955. Print.

Schaeffer, Francis A. Back to Freedom and Dignity. In The Complete Works of Francis A. Schaeffer, Vol. 1. Westchester: Crossway Books, 1982: 357-391. Print.

---. Escape from Reason. Downers Grove: InterVarsity Press, 1968. Print.

---. Genesis in Space and Time. In The Complete Works of Francis A. Schaeffer, Vol. 2 Westchester: Crossway Books, 1982: 3-71. Print.

---. He Is There and He Is Not Silent. In The Complete Works of Francis A. Schaeffer. Vol.1. Westchester: Crossway Books, 1982: 275-352. Print.

---. How Should We Then Live? Old Tappan: Fleming H. Revell Company, 1976. Print. .

---. The God Who Is There. In The Complete Works of Francis A. Schaeffer, Vol. 1. Westchester Crossway Books, 1982: 5-202. Print.

---. True Spirituality. In The Complete Works of Francis A. Schaeffer. Vol. 3 Westchester: Crossway Books, 1982: 195-378. Print.

Tyson, Paul. Returning to Reality. Eugene OR Cascade Books, 2014. Print.

Weaver Richard. Ideas Have Consequences. Chicago: University of Chicago Press, 1948. Print.

Editorial, “Mission to Intellectuals.” Time, Jan 11, 1960. Print.

Bruce A. Little, PhD professor emeritus in philosophy, since 1995 has lectured on philosophy and issues related to culture in various venues mostly in universities throughout Europe and is a visiting professor for Ostroh Academy National University. He is director of the Francis A. Schaeffer collection and Francis Schaeffer Society at Southeastern Theological Seminary and serves as president of Forum for Christian Thought. He is published in academic journals both in the United States and Europe, has authored seven books, edited two books, and contributed to several edited books. Currently he lives with his wife in the U.S. state of Maine.

Email: bittle@sebts.edu 